\title{
Coronary pseudolesion: concertina effect
}

\author{
Abhishek Thakur 다 , Sumit Kumar, Anish Kapil, Raghav Bansal
}

Cardiology, All India Institute of Medical Sciences, New Delhi, India

\section{Correspondence to}

Dr. Raghav Bansal; dr.raghavbansal@outlook.com

Accepted 22 June 2021

\section{DESCRIPTION}

A 71-year-old man, a known hypertensive and diabetic, presented with inferior wall myocardial infarction within window period of $90 \mathrm{~min}$. He was successfully thrombolyzed with $35 \mathrm{mg}$ of tenecteplase and was further planned for pharmacoinvasive therapy; coronary angiography revealed mid-right coronary artery (RCA) diffuse significant stenosis following a proximal tortuosity.

Percutaneous intervention to RCA was planned. For RCA stenting, a 6F JR4 (Medtronic) guiding catheter was taken to engage the RCA. A 0.014-inch Balance Middle Weight guidewire (Abbott Vascular) was used to cross the lesion. After guidewire introduction into RCA, a new lesion was noticed proximal to the diseased segment in proximal RCA which was not present before (figure $1 \mathrm{~A}, \mathrm{~B}$ ). A Promus Element (Boston Scientific) $2.75 \times 32 \mathrm{~mm}$ stent was deployed in mid RCA lesion and post stent dilatation was done. The angiograms showed satisfactory result in the stented segments with no significant stenosis; however, the lesion persisted in proximal RCA segment despite use of intra coronary nitrates. A possibility of coronary dissection was kept, however, the lesions disappeared after guidewire withdrawal (figure 2).

Concertina effect or accordion effect is angiographic appearance of a tortuous coronary vessel after being crossed with a guidewire. ${ }^{1}$ It occurs due to straightening of a tortuous coronary artery by a coronary equipment that stretches the artery, which leads to invagination of excess tissue. The angiographic appearance is thought likely to be folds of redundant endothelium. Since the angiographic appearance resembles coronary dissection or intracoronary thrombus, this entity has to be kept in mind to avoid unnecessary interventions. Coronary spasm is another differential diagnosis. Careful observation of preintervention and postwiring angiograms by an astute interventionist helps to

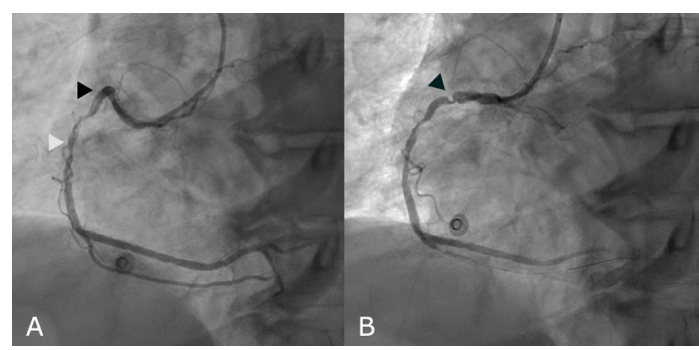

Limited 2021. No commercial re-use. See rights and permissions. Published by BMJ.

To cite: Thakur A, Kumar $S$, Kapil A, et al. BMJ Case Rep 2021;14:e243311. doi:10.1136/bcr-2021243311
Figure 1 (A) Coronary angiogram of right coronary (RCA) artery showing diffuse mid RCA stenosis (white arrowhead) and tortuous bend at the proximal RCA (black arrowhead). (B) Coronary angiogram of RCA immediately after introduction of guidewire showing new pseudo stenotic lesion in proximal RCA (black arrowhead).

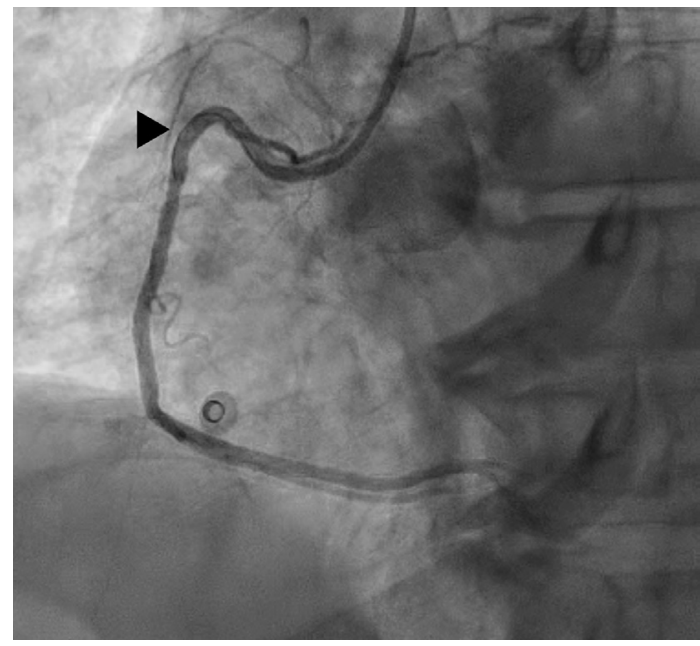

Figure 2 Coronary angiogram of RCA after withdrawal of guidewire showing disappearance of pseudo lesion (black arrowhead). RCA, right coronary artery.

make a diagnosis of concertina effect. ${ }^{2}$ To confirm the diagnosis, one needs to partially withdraw the guidewire to leave only the floppy radio-opaque part of the guidewire across the suspected segment while maintaining a distal guidewire access. This allows the coronary segment to resume its tortuous shape and the pseudolesion disappears with this manoeuvre (figure 2). Although any vessel may be affected, most literature have described it in RCA or left internal mammary artery.

In most cases, they do not have any clinical implication, however, a small risk of ischaemia is present in prolonged cases. Avoiding unnecessary intervention for such a 'pseudolesion' is of paramount importance. $^{3}$

\section{Learning points}

- Concertina effect is a pseudocomplication of coronary angiography which resembles dissection, spasm.

- It is important to identify it because undue coronary interventions may be performed if not identified correctly.

- Partial withdrawal of the guidewire leaving the radiopaque part across the pseudolesion allows the coronary segment to resume its tortuous shape.

Twitter Anish Kapil @akapil15 and Raghav Bansal @bansalrags

Contributors AT and SK were involved in conceptualisation and drafting of manuscript. RB and AK were involved revision of the manuscript and patient care. All the authors discussed the results and implications and commented on the manuscript at all stages. 


\section{Images in...}

Funding The authors have not declared a specific grant for this research from any funding agency in the public, commercial or not-for-profit sectors.

Competing interests None declared.

Patient consent for publication Obtained.

Provenance and peer review Not commissioned; externally peer reviewed.

\section{ORCID iD}

Abhishek Thakur http://orcid.org/0000-0003-2007-1925

\section{REFERENCES}

1 Muller O, Hamilos M, Ntalianis A, Olivier M, Michalis H, Argyris N, et al. Images in cardiovascular medicine. The accordion phenomenon: lesson from a movie. Circulation 2008;118:e677-8.

2 Doshi S, Shiu MF. Coronary pseudo-lesions induced in the left anterior descending and right coronary artery by the angioplasty guide-wire. Int J Cardiol 1999;68:337-42.

3 Goel PK, Agarwal A, Kapoor A, Pravin K, Ajay A, Aditya K. "Concertina" effect during angioplasty of tortuous right and left coronary arteries and importance of using overthe-wire system: a case report. Indian Heart J 2001;53:87-90.

Copyright 2021 BMJ Publishing Group. All rights reserved. For permission to reuse any of this content visit

https://www.bmi.com/company/products-services/rights-and-licensing/permissions/

BMJ Case Report Fellows may re-use this article for personal use and teaching without any further permission.

Become a Fellow of BMJ Case Reports today and you can:

- Submit as many cases as you like

- Enjoy fast sympathetic peer review and rapid publication of accepted articles

- Access all the published articles

- Re-use any of the published material for personal use and teaching without further permission

Customer Service

If you have any further queries about your subscription, please contact our customer services team on +44 (0) 2071111105 or via email at support@bmj.com.

Visit casereports.bmj.com for more articles like this and to become a Fellow 